\title{
BOHEMIAN WAXWINGS FEED ON SCALE INSECTS
}

DALE HJERTAAS and PAULE HJERTAAS, 919 Cook Crescent, Regina, Saskatchewan. S4X 2L9

The flocks of Bohemian Waxwings which brighten our winters are normally thought of as berry eaters, although they will also take buds of poplar and seeds of Box Elder, Black Birch, Locust and Hollyhock. In summer they take up flycatching. However, as far as we can determine, Bohemian Waxwings have not previously been noted to search for and take large numbers of dormant insects in winter.

About 1500 h, 23 November 1980 , we were walking at the Saskatoon Forestry Farm birding and taking photographs. Dale noted 30 Bohemian Waxwings in a row of Manitoba Maple and Green Ash and another 150 waxwings across the road. He approached the first group hoping for photos.

While waiting for the perfect photo he realized that these waxwings were not taking tree buds as assumed. Instead they were removing bumps which practically covered the bottoms of some branches.

Consultation with Paule followed. The bumps were scale insects (superfamily Coccoidea). Female scale insects are sedentary. They settle to suck sap from a tree and develop a scale over their body for protection. Eggs are laid under the scale and the female dies at summer's end. The scales resemble tree buds to the casual observer.

On 7 December Dale observed about 250 Bohemian Waxwings at the Forestry Farm. Most seemed to be feeding on scale insects whose numbers were being rapidly reduced.

This observation sparked our curiousity. How effective would the waxwings be in controlling the scale insect population. Fortunately, removal of a scale insect left a visible spot on the bark, allowing an easy count of numbers taken. On 13 December we therefore returned to the Forestry Farm to do some counts.

Our technique worked well except the intense cold forced a reduction in sample size when Paule could no longer write! We checked 4 branch sections between 6 and 12 feet above ground level. On these sections we found scars where 707 scales had been removed. We also found 49 intact scales; $93.5 \%$ of the scales had been removed.

Since Bohemian Waxwings were the only agent we observed taking the scale insects, we assumed they were responsible for at least most of the removal. This level of insect control was probably as much as would be achieved. On 13 December only 50 Bohemian Waxwings were in the general area, none were observed searching for scale insects at this location, nor was this observed later in the winter. Presumably the law of diminishing returns sent the flock elsewhere after removing over $90 \%$ of the food supply.

Is this an unusual feeding habit for Bohemian Waxwings? The 1980 fruit crop was very poor. By late November 
the berry supply around the Forestry Farm was getting low. Perhaps this forced waxwings to search for alternte food. Or did this flock just luck out and find a preferred protein-rich food supply at a convenient time?
'BENT, A.C. 1950. Life Histories of North American wagtails, shrikes, vireos and their allies. Smithsonian institute, U.S. National Museum Bull. 197.

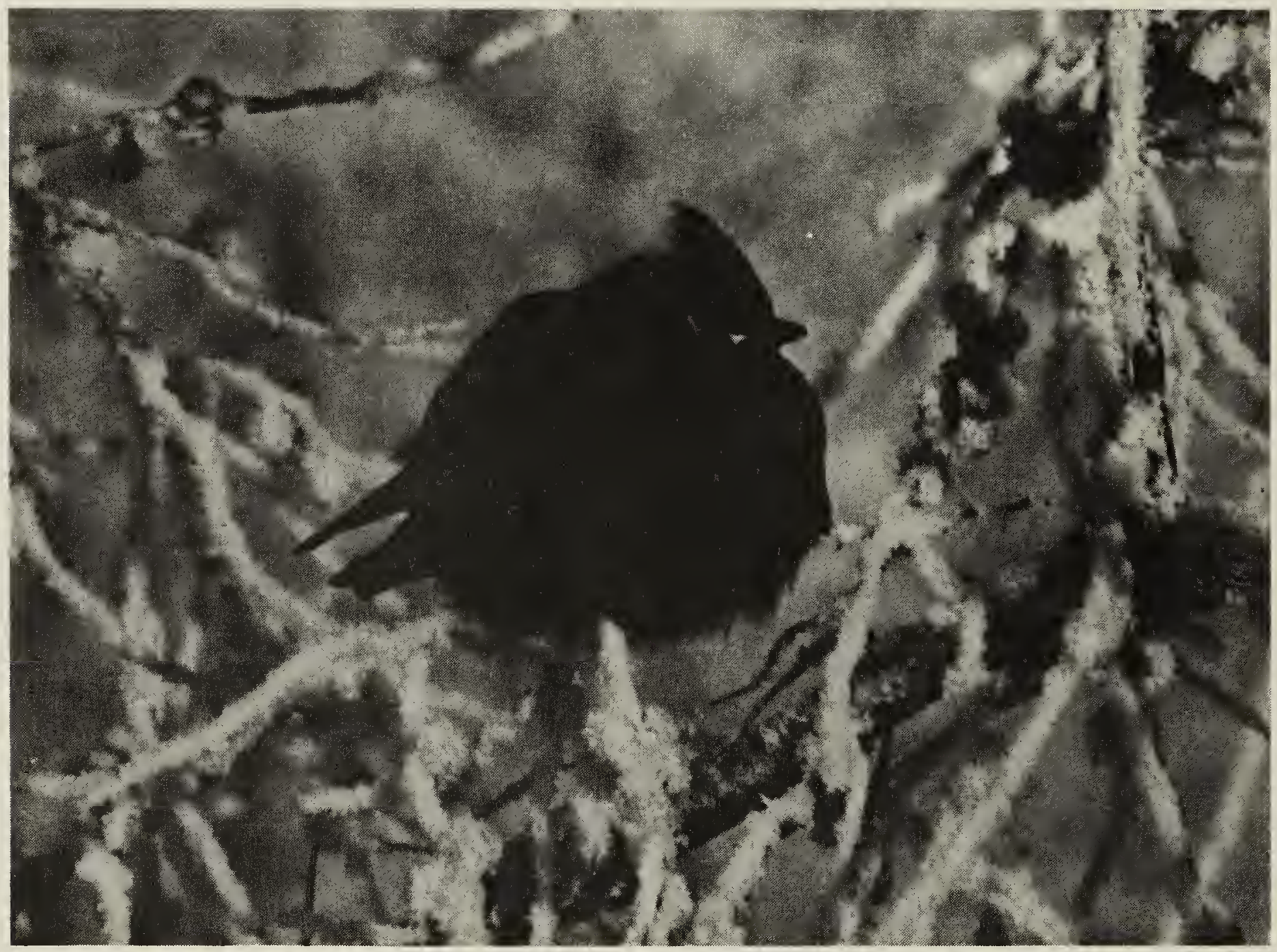

Bohemian Waxwing

Juhachi Asai

\section{RUFOUS HUMMINGBIRD SIGHTING}

JEAN HILTON and GEORGE HILTON, R.R. \# 1, Bangor, Saskatchewan. SOA OEO

In Saskatchewan parkland, about 25 miles north of Round Lake (Qu'Ap. pelle Valley), we usually have a pair of Ruby-throated Hummingbirds around the yard each year and we thoroughly enjoy watching them as they dart from flower to flower sipping nectar.

Christmas 1983 delivered a hummingbird feeder which we hung about 3 feet in front of the kitchen 